\title{
Performance measurement of R\&D is a vaccine for innovation capability: evidence from Indian manufacturing organisations
}

\author{
Sushanta Tripathy* \\ National Institute of Science and Technology Business School, \\ Palur Hills, Berhampur, Orissa, 761008, India \\ E-mail: sushant.tripathy@gmail.com \\ *Corresponding author
}

\section{Pradip Kumar Ray and Sadananda Sahu}

Department of Industrial Engineering and Management, Indian Institute of Technology, Kharagpur, 721302, India

E-mail: pkr@vgsom.iitkgp.ernet.in

E-mail: sahus@mech.iitkgp.ernet.in

\begin{abstract}
The purpose of this study is to explore the barriers and critical success factors that affect the R\&D organisational performance in Indian manufacturing scenario. Reviewing the literatures on R\&D performance measurement in manufacturing organisations, this paper first brings out a number of key factors contributing to the R\&D organisational performance. Based on these factors, a questionnaire survey was conducted among the different manufacturing sectors. An analysis of the responses to the questionnaire survey, together with the use of principal component analysis and factor analysis, helped in framing five constructs: R\&D productivity, TQM index, roadblocks to R\&D, technical competency, and effectiveness of R\&D. Using these constructs, seven hypotheses were developed and tested in the framework of structural equation modelling. The results indicate that technical competency and TQM index are the key drivers to encourage the performance of $R \& D$, which enhance effectiveness of $R \& D$ in manufacturing sectors in Indian scenario.
\end{abstract}

Keywords: research and development; R\&D; performance measurement; principal component analysis; PCA; structural equation modelling; SEM; India.

Reference to this paper should be made as follows: Tripathy, S., Ray, P.K. and Sahu, S. (2011) 'Performance measurement of R\&D is a vaccine for innovation capability: evidence from Indian manufacturing organisations', Int. J. Electronic Transport, Vol. 1, No. 1, pp.76-95.

Biographical notes: Sushanta Tripathy is currently working as an Assistant Professor in the Department of Business Administration, National Institute of Science and Technology Business School, Berhampur, Orissa, India. He obtained his $\mathrm{PhD}$ from the Department of Industrial Engineering and Management, Indian Institute of Technology, Kharagpur. He has over 20 years of teaching, research and industry experience in India and abroad. His research interests include operations management, productivity management and multivariate analysis. 
Pradip Kumar Ray is currently a Professor in the Department of Industrial Engineering and Management, Indian Institute of Technology Kharagpur, India. He has eight years of industrial and 22 years of teaching and research experience in India and abroad. He has published around 120 papers in international and national journals of repute and has secured substantial number of research grants and industrial consulting in his research areas. He has supervised $12 \mathrm{PhD}$ scholars and coordinated several training programmes for industries. He is certified Lead Assessor for ISO-9001 registration, member of INFORMS and IIMM, and Fellow of WAPS.

Sadananda Sahu is currently working as a Professor in the Department of Industrial Engineering and Management, Indian Institute of Technology, Kharagpur. He has published around 40 papers in referred journals like International Journal of Production Economics, International Journal of Production Research, and international conferences. He has successfully guided $14 \mathrm{PhD}$ scholars during his 39 years of teaching and research at IIT, Kharagpur. He was a member of the editorial board of International Journal of Production Research for several years and a Fellow of WAPS.

\section{Introduction}

Performance measurement of organisations has been the spotlight of various authors. Many authors (e.g., Kerssen-van Drongelen and Cook, 1997; Driva et al., 2000; Frattini et al., 2006) concentrate on assessment of performance of organisations; some extracts are given below to sustain the same. According to Harrington (1994) "Measurement is the first step that leads to control and eventually to improvement. If you can't measure something, you can't understand it. If you can't understand it, you can't control it. And if you can't control it you can't improve it". The performance measurement of an organisation depends on various factors, such as effectiveness, efficiency, quality, profitability, quality of work life, innovation, productivity and the technology adopted (Sink, 1985).

According to Barney (1991), in order for an asset to be a source of competitive advantage for a firm, it has to be:

1 valuable

2 rare

3 difficult to imitate

4 difficult to substitute.

Capability is defined as an integration of these various kinds of special assets possessed by the organisation. A firms' innovation capabilities are important in providing and sustaining its competitive advantage, and in the implementation of the entire strategy (Guan and Ma, 2003). Innovational capability is the core of technological capability (Lee et al., 2008). Innovational capability improves competitive and economic performance of firms (Zhang et al., 2010).

Factors influencing research and development (R\&D) practices differ from one country to another, indicating the effect of diverse socio-culture settings of the countries around the world. Indian companies have long been criticised for their low level of 
investment in R\&D, both in India and other parts of the world. This fact has prevented them from becoming serious players in global markets (Wharton Knowledge, 2005). Today, however, the scenario looks different, perhaps not vastly, but certainly noticeably. A few sectors like pharmaceuticals and automobiles are taking the lead in the R\&D field, with expenditures rising disproportionately to sales growth (Mitra, 2007).

In India, the total R\&D expenditure is $0.85 \%$ of GDP and its position is 30th out of 80 in global scenario (National S\&T Survey, 2005; Chandra, 2009; CMIE, 2009). The researchers in R\&D are 119.05 per million people and takes global position of 43rd out of 54 countries involved in research activities. Total scientific and journal articles are 14,608 , which consider the 29th position out of 68 globally. Similarly, high-technology exports (\% of manufactured exports) are $5.7 \%$ of GDP, which takes 53 rd position out of 82 countries involved in high-technology exports.

In order to ensure the Indian manufacturing firms survival in the global market, now these manufacturing firms have to choose a more appropriate and feasible strategy that would increase their technological knowledge base as well as improve their innovational capability. India is one of the hubs for the developed nations to outsource their R\&D activities. Except some specific sectors like automobiles and pharmaceuticals, the output of R\&D performance of the Indian manufacturing firms has not impressed the global market still now.

In the light of the above view-points, the immediate research question that this paper attempts to answer is: which factors contribute positively, and negatively (barriers) to the $R \& D$ activities of Indian manufacturing sectors? And finally, what are their causal relationships?

The following objectives have been set for this research question: to identify the critical success factors and barriers for performance measurement of $R \& D$ organisations, group them into most prominent categories, determine the causal relationships among them and find the most influential categories that help in performance measurement of R\&D activities of Indian manufacturing organisations.

The structure of the paper is as follows: Section 2 summarises, in a tabular form, the findings drawn from the past works on key performance indicators of R\&D. Section 3 gives some details of the questionnaire survey. Section 4 presents the analysis of the responses to the questionnaire survey using principal component analysis (PCA) which brings out a list of important success factors and barriers and groups them into broad categories and discusses the use of SEM framework to find causal relationships among the broad categories of factors. In Section 5, the SEM approach has done to test the hypothesis. Section 6 entails the path model derived from SEM analysis and Section 7 discusses the conclusions drawn from the study.

\section{Literature review}

An extensive literature review has been carried out to find out the governing factors affecting R\&D performance measurement. Many studies have ascertained the significance of performance measurement of the R\&D organisations, and the correlated difficulties such as technology enablers, productivity measurement, market focus, types of measurement models and bottlenecks in R\&D organisation. 
Table 1 below gives literature review of R\&D performance measurement. Column 1 of Table 1 gives a list of selected studies done for R\&D performance measurement. Columns 2 and 3 of Table 1 show study objectives and the findings respectively.

Table 1 A literature review of R\&D performance measurement

\begin{tabular}{|c|c|c|}
\hline Author(s) & Objective & Findings \\
\hline Driva et al. (2000) & $\begin{array}{l}\text { The different factors } \\
\text { affecting R\&D } \\
\text { performance in academics } \\
\text { and industry }\end{array}$ & $\begin{array}{l}\text { The interesting results of the study tell that } \\
\text { a nice gap does exist between the measures } \\
\text { recommended by the academics and those } \\
\text { used in real practice. The main difference } \\
\text { lies in the fact that companies use basic time, } \\
\text { cost and quality measures, whereas there is an } \\
\text { increased use of customer-related measures in } \\
\text { academics. }\end{array}$ \\
\hline Akcakaya (2001) & $\begin{array}{l}\text { Developed model } \\
\text { using qualitative and } \\
\text { quantitative indicators }\end{array}$ & $\begin{array}{l}\text { The author presents a model for assessing } \\
\text { R\&D effectiveness. Quantitative information } \\
\text { is categorised in to general, product } \\
\text { development, technology development } \\
\text { and technology sales, whereas qualitative } \\
\text { self-assessment criteria are categorised in to } \\
\text { intangible results, conditions and methods. }\end{array}$ \\
\hline $\begin{array}{l}\text { Loch and Tapper } \\
(2002)\end{array}$ & $\begin{array}{l}\text { Developed a } \\
\text { comprehensive } \\
\text { performance } \\
\text { measurement. }\end{array}$ & $\begin{array}{l}\text { The study describes a process of developing } \\
\text { and implementing a comprehensive } \\
\text { performance measurement system using } \\
\text { strategic alignment and prioritisation, } \\
\text { evaluation and incentives, operational control, } \\
\text { and learning and improvement for an applied } \\
\text { research group. }\end{array}$ \\
\hline Kim and Oh (2002) & $\begin{array}{l}\text { Performance of R\&D } \\
\text { according to various } \\
\text { types of R\&D }\end{array}$ & $\begin{array}{l}\text { Categorisation is made on the basis of the } \\
\text { type of } R \& D \text { in a survey of effective R\&D } \\
\text { performance measurement systems in Korea. }\end{array}$ \\
\hline Coccia (2003) & $\begin{array}{l}\text { Performance measurement } \\
\text { of research laboratory. }\end{array}$ & $\begin{array}{l}\text { Two general models to assess the R\&D } \\
\text { performance of a public research lab are } \\
\text { presented here. }\end{array}$ \\
\hline Roy et al. (2003) & $\begin{array}{l}\text { Developed model to } \\
\text { measure the effectiveness } \\
\text { of research units. }\end{array}$ & $\begin{array}{l}\text { This study emphasises on development of } \\
\text { a model to measure the effectiveness of } \\
\text { research units. }\end{array}$ \\
\hline Germerrad (2003) & $\begin{array}{l}\text { Technical competency is } \\
\text { an important factor for } \\
\text { performance measurement } \\
\text { of R\&D. }\end{array}$ & $\begin{array}{l}\text { Here, it is stated that developing } \\
\text { meaningful R\&D metrics is not only a } \\
\text { technical competency but one which can be } \\
\text { applied to other corporate functions as well. }\end{array}$ \\
\hline $\begin{array}{l}\text { Heshmati and Loof } \\
(2005)\end{array}$ & $\begin{array}{l}\text { Determined the } \\
\text { relationship between } \\
\text { R\&D investment and } \\
\text { productivity. }\end{array}$ & $\begin{array}{l}\text { This study determines correlation and } \\
\text { causality between sources of finance, } \\
\text { R\&D investment and productivity }\end{array}$ \\
\hline Kuittinen (2007) & $\begin{array}{l}\text { Determined the } \\
\text { relationship between } \\
\text { R\&D investment and } \\
\text { innovative performance. }\end{array}$ & $\begin{array}{l}\text { From this study it can be interpreted that } \\
\text { the relationship between corporate R\&D } \\
\text { investments and innovative performance is } \\
\text { not so straight forward, however, the nature } \\
\text { of innovation activity is strongly influenced } \\
\text { by the industry which the firm operates in. }\end{array}$ \\
\hline
\end{tabular}


Table 1 A literature review of R\&D performance measurement (continued)

\begin{tabular}{|c|c|c|}
\hline Author(s) & Objective & Findings \\
\hline Mitra (2007) & $\begin{array}{l}\text { It examines key trends, } \\
\text { drivers and future } \\
\text { prospects for R\&D } \\
\text { developments in India. }\end{array}$ & $\begin{array}{l}\text { The objective of this study is to provide } \\
\text { a strategic review of corporate R\&D } \\
\text { developments in India. It examines key trends, } \\
\text { drivers and future prospects for R\&D with a } \\
\text { special focus on India's emerging role as an } \\
\text { attractive location for R\&D and knowledge } \\
\text { process service industries. }\end{array}$ \\
\hline $\begin{array}{l}\text { Smith and Ball } \\
(2007)\end{array}$ & Innovational capability. & $\begin{array}{l}\text { Innovation is an established factor for } \\
\text { competitive success and has been linked } \\
\text { traditionally to product and process } \\
\text { technology. }\end{array}$ \\
\hline Howells (2008) & $\begin{array}{l}\text { Key dimensions of } \\
\text { R\&D performance } \\
\text { measurement. }\end{array}$ & $\begin{array}{l}\text { Shared laboratories, 'Pico' R\&D } \\
\text { establishment, transparency R\&D unit, } \\
\text { consumer engaged research unit are the } \\
\text { important dimensions of R\&D performance. }\end{array}$ \\
\hline $\begin{array}{l}\text { García-Valderrama } \\
\text { et al. (2008) }\end{array}$ & $\begin{array}{l}\text { Used BSC model to } \\
\text { measure the performance } \\
\text { of R\&D. }\end{array}$ & $\begin{array}{l}\text { The BSC model for R\&D developed in } \\
\text { this study has been subject to testing with } \\
\text { recognised experts in management and in } \\
\text { R\&D and grouped under five broad } \\
\text { perspectives of the BSC. }\end{array}$ \\
\hline Pereda et al. (2008) & $\begin{array}{l}\text { Product development, } \\
\text { manufacturing process } \\
\text { development and } \\
\text { manufacturing system } \\
\text { development. }\end{array}$ & $\begin{array}{l}\text { A review and analysis of the product lifecycle, } \\
\text { paying attention in a business and engineering } \\
\text { perspective, is first presented as a base for the } \\
\text { description and analysis of the interrelations } \\
\text { among: product development, manufacturing } \\
\text { process development and manufacturing } \\
\text { system development focused on the entire } \\
\text { lifecycle concept. }\end{array}$ \\
\hline Lee (2009) & $\begin{array}{l}\text { R\&D performance } \\
\text { based on technological } \\
\text { competence or R\&D } \\
\text { productivity. }\end{array}$ & $\begin{array}{l}\text { A firm's R\&D response to competitive } \\
\text { market pressure depends primarily on its } \\
\text { level of technological competence or R\&D } \\
\text { productivity }\end{array}$ \\
\hline $\begin{array}{l}\text { O’Mahony and } \\
\text { Vecchi (2009) }\end{array}$ & $\begin{array}{l}\text { Role of knowledge } \\
\text { spillover on R\&D } \\
\text { productivity performance. }\end{array}$ & $\begin{array}{l}\text { A knowledge spillover is the key indicator for } \\
\text { R\&D productivity performance. }\end{array}$ \\
\hline $\begin{array}{l}\text { Narayanan and Bhat } \\
(2009)\end{array}$ & $\begin{array}{l}\text { Determined the } \\
\text { relationship between } \\
\text { import of technology and } \\
\text { in-house R\&D }\end{array}$ & $\begin{array}{l}\text { This study determines a substitutive } \\
\text { relationship between import of technology and } \\
\text { in-house R\&D. Firm size and age also emerge } \\
\text { significant in determining R\&D intensity. }\end{array}$ \\
\hline $\begin{array}{l}\text { Pulkkinen and } \\
\text { Riitahuhta (2009) }\end{array}$ & $\begin{array}{l}\text { Engineering changes, } \\
\text { product structuring and } \\
\text { business processes. }\end{array}$ & $\begin{array}{l}\text { Business operation is related to constraints on } \\
\text { the engineering change management, product } \\
\text { structures and product development processes. }\end{array}$ \\
\hline Swain et al. (2009) & $\begin{array}{l}\text { Reduction of time and } \\
\text { cost. }\end{array}$ & $\begin{array}{l}\text { In order to reduce the time and manufacturing } \\
\text { cost to develop a product, relationship } \\
\text { between the product model and process } \\
\text { model is important. }\end{array}$ \\
\hline
\end{tabular}


Table 1 A literature review of R\&D performance measurement (continued)

\begin{tabular}{|c|c|c|}
\hline Author(s) & Objective & Findings \\
\hline Tsai (2009) & $\begin{array}{l}\text { Emphasised collaborative } \\
\text { networks and product } \\
\text { innovation performance. }\end{array}$ & $\begin{array}{l}\text { Collaborative networks and product } \\
\text { innovation performance are key } \\
\text { factors of R\&D productivity }\end{array}$ \\
\hline $\begin{array}{l}\text { Bigliardi and } \\
\text { Dormio (2010) }\end{array}$ & $\begin{array}{l}\text { The aim of this paper } \\
\text { is to develop a balanced } \\
\text { scorecard (BSC) model } \\
\text { delimited for research } \\
\text { and development (R\&D) } \\
\text { performance } \\
\text { measurement. }\end{array}$ & $\begin{array}{l}\text { The preliminary result obtained from this } \\
\text { case study, that is a BSC model suitable for } \\
\text { R\&D, helps in the development of a general } \\
\text { BSC model to be tested on a wide sample of } \\
\text { firms that actively operate in the R\&D field. }\end{array}$ \\
\hline $\begin{array}{l}\text { Griffiths and } \\
\text { Webster (2010) }\end{array}$ & $\begin{array}{l}\text { Two parallel streams of } \\
\text { research investigating the } \\
\text { determinants of corporate } \\
\text { R\&D exist: one from } \\
\text { economics and the other } \\
\text { from management. }\end{array}$ & $\begin{array}{l}\text { The results suggest that most of a firm's } \\
\text { R\&D activity is explained by time-invariant } \\
\text { factors which we believe are predominantly } \\
\text { characteristics that are internal and specific to } \\
\text { the firm. }\end{array}$ \\
\hline
\end{tabular}

The past works included in Table 1 mainly focus on factors affecting R\&D performance measurement. The major factors identified in these works are described in the next section.

Certain points need to be highlighted like the ones given below. Most of the R\&D organisations measure their R\&D performance according to different dimensions, and, thus, studying factors underlying the R\&D performance is very crucial. Factors influencing R\&D performance measurement differ from country to country, research laboratory to research laboratory, firm to firm, etc. For instance, collaborative research and innovative performance are the key factors affecting R\&D performance measurement in big firms (Tsai, 2009; Howells, 2008). On the other hand, firm size and technical competency are significant determinants of R\&D performance measurement in small firms (Germerrad, 2003; Narayanan and Bhat, 2009; Lee, 2009).

The productivity focus shifts to organisational areas where the inputs and outputs are either difficult to define, to measure, or are interconnected in fuzzy and complex ways. Professional and service organisations, such as corporate R\&D divisions, are typical (Brown and Gobeli, 1992). R\&D productivity comprises of

1 firm size and resources

2 organisational processes and procedures

3 R\&D expenditure

4 mobilisation of R\&D personnel.

Technological competency is valuable because it leads to product improvements that increase the value of the product and process improvements that reduce the firm's cost structure. The competitive advantages created from a firm's technological capabilities usually have a high degree of causal ambiguity because firms without similar technical skills have difficulty understanding why or how product and process improvements are made. The different factors involved here are: 
1 quality and size of R\&D personnel

2 products and processes developed

3 R\&D collaboration.

TQM is considered as a prerequisite of innovation. R\&D management is an appropriate resource to be used in harmony with TQM to enhance organisational performance (Prajogo and Sohal, 2006). Factors like

1 measurement of $R \& D$ performance

2 R\&D cycle time

3 formal benchmarking shape the R\&D organisations to very much effective.

Roadblocks to R\&D puts barrier to achieve innovational capability. The factors associated with roadblocks to $R \& D$ are:

1 supply of critical material and parts

2 technological uncertainties

3 innovation risk

4 in-house resource constraints.

Finally, R\&D effectiveness based on

1 accomplishment of R\&D objectives

2 innovativeness and productiveness

3 cross functional team work

4 linking R\&D with production and marketing.

In spite of its inherent infrastructure facilities, skilled manpower and sound IT strength, India has not impressed much in $\mathrm{R} \& \mathrm{D}$ productivity measurement due to unexplored factors. Furthermore, no reported studies have attempted to clearly recognise most influential factors affecting Indian R\&D performance.

\section{Questionnaire survey}

R\&D performance depends on a number of factors. Factors related to barriers and critical success in respect of R\&D performance measurement were extracted from the reported past works as mentioned in literature review (Table 1), and, findings from Third National Manufacturing Survey (Chandra, 2009). The barriers to R\&D productivity performance and critical success factors for R\&D productivity performance are listed in Tables 2 and 3 respectively, along with their sources.

A questionnaire was designed reflecting the barriers and critical success factors identified in the past works. Two sections of the questionnaire addressed these issues, one 
section devoted to each one of these issues. The barriers section contained 14 statements, whereas the section on critical success factors contained 26 statements. Each respondent was asked to indicate the degree to which he (or she) agreed with the statement in a five-point Likert scale. An example of the barrier section is as follows: supply of critical material and parts is a barrier to R\&D productivity performance. Please give your rating against this statement in the scale of 1-5 (1: strongly disagree, 2: do not agree, 3: somewhat agree, 4: agree, 5: strongly agree).

Pilot testing was done by 30 personnel of various R\&D organisations to ensure that no important dimensions were missed out. Taking these factors, an open questionnaire was prepared. Purpose of pilot-testing was to refine the format, add, remove and rephrase several items before sending the questionnaire out to users. After a few iterative reconsiderations and consecutive improvements in the questionnaire we have formulated the final questionnaire. The statements were refined and rephrased in the light of the feedback obtained in the pilot test prior to launching the final questionnaire survey. A cross-sectional field survey was carried out using self-administered questionnaire. 650 personnel of various R\&D organisations from the different states of India were personally requested to participate in the survey, 291 responses were received out of which 262 questionnaires were properly filled. A low response of $45 \%$ indicates that most of the Indian manufacturing firms are not involved in any type of research activities, such as basic research, applied research, product development, and process development

Table 2 Barriers to R\&D productivity performance

\begin{tabular}{|c|c|}
\hline Sources & Barriers \\
\hline \multirow{4}{*}{$\begin{array}{l}\text { Freeman and Soete (2009), } \\
\text { O'Mahony and Vecchi (2009) and } \\
\text { Boutellier et al. (2008) }\end{array}$} & Immaturity of technology \\
\hline & Insufficient financial support \\
\hline & In-house resource constraints \\
\hline & Bottlenecks to R\&D organisation \\
\hline \multirow{3}{*}{$\begin{array}{l}\text { Werner and Souder (1997), } \\
\text { Nemet (2009) and Chandra (2009) }\end{array}$} & Supply of critical material and parts \\
\hline & Innovation risk \\
\hline & Technological uncertainties \\
\hline \multirow{3}{*}{$\begin{array}{l}\text { Cooper and Kleinschmidt (1996) and } \\
\text { Loch and Tapper (2002) }\end{array}$} & Transferring technology to manufacturing \\
\hline & Linking R\&D to business planning \\
\hline & Lack of skill and knowledge \\
\hline \multirow{3}{*}{$\begin{array}{l}\text { Lee (2009), O'Mahony and Vecchi } \\
\text { (2009) and Narayanan and Bhat (2009) }\end{array}$} & Knowledge spillover \\
\hline & Rent spillover \\
\hline & R\&D expenditure \\
\hline \multirow{3}{*}{$\begin{array}{l}\text { Howells (2008), Chandra (2009) and } \\
\text { Jayawarna and Holt (2009) }\end{array}$} & No demand for innovation \\
\hline & Long time taken for $R \& D$ to reach the market \\
\hline & Inadequate tax incentives for investment in $R \& D$ \\
\hline \multirow[t]{4}{*}{ Chandra (2009) } & Lack of information technology \\
\hline & Difficulty in finding partners \\
\hline & Excessive government regulation in some regions \\
\hline & Bureaucracy of the system \\
\hline
\end{tabular}


Table 3 Critical success factors for R\&D productivity performance

\begin{tabular}{lc}
\hline Sources & Critical success factors \\
\hline Curtis and Ellis (1997), Kuittinen & Firm size, customer focus \\
(2007) and Lee (2009) & Alliance with the partner \\
& Market orientation \\
Akcakaya (2001), Narayanan and Bhat & Cross functional team \\
(2009) and Driva et al. (2000) & Imported and domestic technologies \\
& Prevention focus \\
Howells (2008) & Firm resources \\
& Shared laboratories \\
Boutellier et al. (2008), O’Mahony and & Transparency in R\&D unit \\
Vecchi (2009) and Nemet (2009) & Consumer engaged research unit \\
& Market orientation \\
Heshmati and Loof (2005), Mitra (2007) & Market position \\
and Howells (2008) & Technology push and demand pull \\
& 'Pico' R\&D establishment \\
Khiesa and Masella (1996), & Knowledge process service industries \\
and García-Valderrama et al. (2008) & R\&D investment \\
\hline & Effective utilisation of resources \\
& Knowledge spillover \\
& R\&D effectiveness \\
\hline
\end{tabular}

\section{Analysis of the results}

\subsection{Profile of the respondents}

Table 4 indicates the profile of the primary industries where the questionnaire was administered, and the number of R\&D personnel who participated in the survey.

Table 4 Profile of the respondent primary industries

\begin{tabular}{lc}
\hline Primary industry & Number of participants \\
\hline Steel & 37 \\
Aluminium & 34 \\
Materials & 33 \\
Heavy engineering parts & 31 \\
Textiles & 27 \\
Paper & 24 \\
Cement & 31 \\
Power sectors & 23 \\
Others & 22 \\
Total & 262 \\
\hline
\end{tabular}


Tables 5, 6, 7 and 8 respectively show the profile of the respondents, indicate their educational qualifications, R\&D-related experience, gender, and job profile.

Table 5 Educational qualification of the respondents

\begin{tabular}{lcc}
\hline Education & Frequency & Percentage \\
\hline Higher secondary/diploma & 55 & 21 \\
Bachelor's degree & 107 & 41 \\
Master's degree & 79 & 30 \\
Doctorate & 21 & 8 \\
Total & 262 & 100 \\
\hline
\end{tabular}

Table 6 Experience in related functions

\begin{tabular}{lcc}
\hline Experience & Frequency & Percentage \\
\hline Less than three years & 47 & 18 \\
3-6 years & 67 & 25 \\
$7-10$ years & 126 & 48 \\
More than ten years & 22 & 9 \\
Total & 262 & 100 \\
\hline
\end{tabular}

Table 7 Gender of respondents

\begin{tabular}{lcc}
\hline Gender & Frequency & Percentage \\
\hline Male & 238 & 91 \\
Female & 24 & 9 \\
Total & 262 & 100 \\
\hline Table 8 Job profile & & \\
\hline Job position & Frequency & Percentage \\
\hline Senior manager & 51 & 19 \\
Manager & 112 & 43 \\
Assistant manager & 58 & 22 \\
Office support staff & 41 & 16 \\
Total & 262 & 100 \\
\hline
\end{tabular}

\subsection{Principal component analysis}

PCA is one of the best known and most used multivariate exploratory analysis technique. Generally reducing the number of variables used to describe data will lead to some loss of information. PCA operates in a way that makes this loss minimal, in a sense that will be given a precise meaning. Therefore, PCA may be regarded as a dimensionality reduction technique. The goal of dimensionality reduction is to create a small set of new variables that will describe the individuals in the data base nearly as well as do the original variables, which are usually quite numerous. The new variables will exhibit less redundancy than the original variables. 
A factor analysis was performed on the responses to the questionnaires with the help of the SPSS-14 package. Out of 40 factors listed in the questionnaire, 18 factors captured $87 \%$ of the total variance of the data set. A PCA was performed using varimax factor rotation to group the factors and thus determine the category of factors (constructs). Five constructs were formed. Table 9 gives the constructs and their constituent factors. It also gives various statistics (such as mean and standard deviation of scores, factor loading, Cronbach's alpha, and standardised regression weight) for each factor.

Table 9 Constructs derived from the questionnaire

\begin{tabular}{|c|c|c|c|c|c|c|}
\hline & nstructs and constituent factors & Mean & $S D$ & $\begin{array}{l}\text { Factor } \\
\text { loading }\end{array}$ & $\begin{array}{c}\text { Cronbach's } \\
\text { alpha }\end{array}$ & $\begin{array}{l}\text { Standardised } \\
\text { regression }\end{array}$ \\
\hline 1 & R\&D productivity & - & - & - & 0.803 & - \\
\hline & Firm size and resources & 4.4 & 0.6 & 0.823 & & $0.855^{*}$ \\
\hline & Organisational processes and procedures & 4.3 & 0.7 & 0.812 & & $0.889 *$ \\
\hline & R\&D expenditure & 4.4 & 0.6 & 0.797 & & $0.837 *$ \\
\hline & Mobilisation of R\&D personnel & 4.4 & 0.6 & 0.803 & & $0.815^{*}$ \\
\hline 2 & TQM index & - & - & - & 0.843 & - \\
\hline & Measurement of R\&D performance & 4.2 & 0.6 & 0.689 & & 0.821 \\
\hline & Shortening R\&D cycle time & 4.2 & 0.7 & 0.699 & & $0.800^{*}$ \\
\hline & Formal benchmarking & 4.1 & 0.7 & 0.684 & & $0.874 *$ \\
\hline 3 & Roadblocks to R\&D & - & - & - & 0.817 & - \\
\hline & Supply of critical materials and parts & 2.5 & 0.8 & 0.873 & & 0.896 \\
\hline & Technological uncertainties & 2.3 & 0.7 & 0.861 & & $0.818 *$ \\
\hline & Innovation risk & 2.4 & 0.9 & 0.851 & & $0.813^{*}$ \\
\hline & In-house resource constraints & 2.3 & 0.8 & 0.879 & & $0.915^{*}$ \\
\hline 4 & Technical competency & - & - & - & 0.867 & - \\
\hline & Quality and size of R\&D personnel & 4.2 & 0.6 & 0.769 & & $0.855^{*}$ \\
\hline & Products and processes developed & 4.3 & 0.8 & 0.771 & & $0.732 *$ \\
\hline & R\&D collaboration & 4.1 & 0.6 & 0.783 & & $0.831 *$ \\
\hline 5 & R\&D effectiveness & - & - & - & 0.881 & - \\
\hline & Accomplishment of R\&D objectives & 4.2 & 0.7 & 0.655 & & $0.825^{*}$ \\
\hline & Innovativeness and productiveness & 4.2 & 0.8 & 0.651 & & $0.879 *$ \\
\hline & Cross functional team work & 4.1 & 1 & 0.629 & & $0.835^{*}$ \\
\hline & Linking R\&D with production/marketing & 4.2 & 0.7 & 0.617 & & $0.905 *$ \\
\hline
\end{tabular}

Note: *Significant at $p<.01$

Considering the five constructs, shown in Table 9, hypotheses were developed. A PCA is done to capture those features in the data that help to better understand an issue of interest or to discover interesting new patterns among the relationships between variables affecting R\&D performance. Each principal component provides a set of factor loadings of the indicators, which correspond to their importance for the component, i.e., the higher the loading of an indicator, the more useful it is for explaining variation in the direction of the principal component. 
We conventionally decide to eliminate items with factor loading and cronbach's alpha values (Columns 3 and 4) less than 0.6 and 0.8 respectively. The extracted items after the elimination from the comprehensive list of questionnaire are given in Table 9. The purpose of the analysis is to identify and eliminate low factor loadings and non-reliable items.

\subsubsection{Hypotheses on causal relationships among the constructs}

To establish the causal relationships among the categories of factors, we first suggest a set of hypotheses each linking a direct relationship between two categories of factors. The hypotheses are based on findings of the past works and on logical reasoning. We present below the arguments in support of each hypothesis and state the hypothesis in full.

\subsubsection{R\&D productivity and performance of $R \& D$}

In order to sustain their competitive position or to gain new competitive advantage in liberation and globalisation environments, companies need to make more investments in R\&D activities (see e.g., Brown and Gobeli, 1992; Heshmati and Loof, 2005; Kuittinen, 2007). R\&D expenditures having a strong positive co-relation with R\&D productivity (Ding, 2007; Guellecb and Van Pottelsberghe, 2003).

H1 R\&D productivity has a positive effect on performance of $R \& D$.

\subsubsection{Roadblocks to $R \& D$ and $R \& D$ productivity}

Innovation risk, technological uncertainties, improper inventory policy, errors in product and process development lead complications in R\&D, which reflect poor productivity in R\&D organisations. It is crucial that minimising the R\&D bottlenecks is the key solution to enhance the productivity of $R \& D$ organisations (Chandra, 2009). It is essential that error free $R \& D$ organisations having a better market share to stay competitive in the global market and a better productive R\&D organisation minimises the complications in R\&D. Therefore, it is expected that roadblocks to $R \& D$ will have a negative effect on R\&D productivity.

H2 Roadblocks to R\&D organisation has a negative effect on R\&D productivity.

\subsubsection{Technical competency and performance of $R \& D$}

Technical competency facilitates a firm to offer a greater variety of valuable, rare, unique and differentiated products, and therefore lead firms to higher R\&D performance (Barney, 1991; Hitt et al., 1994; Zahra et al., 2000). Improving the technical capability is an important tool for enhancement of performance (Sunil, 2001). The conclusions reached in these past works lead to the following hypothesis:

H3 Technical competency has a positive effect on performance of R\&D.

\subsubsection{Roadblocks to $R \& D$ and TQM index}

Most of the R\&D organisations are facing intra-organisational barriers in the shape of innovation risk and unavailability of critical material to drive the R\&D organisations in 
effective way (Sen and Rubenstein, 1989). Innovation risk and technological uncertainties can be covered through collaborative network. Collaborating with customers is another important technique for a firm to improve the performance of R\&D organisations (Gupta et al., 2000; Fritsch and Lukas, 2001; Brockhoff, 2003). R\&D organisations should be designed with cross functional team with innovativeness and productiveness, drive out the fear against innovation risk, technological uncertainties, and thus support to the following hypothesis:

H4 Roadblocks to R\&D has a negative effect on TQM index.

\subsubsection{TQM index and performance of $R \& D$}

TQM is considered as a prerequisite of innovation. R\&D management is an appropriate resource to be used in harmony with TQM to enhance organisational performance (Prajogo and Sohal, 2006). The integration of TQM and R\&D management was built integrating the firm's dynamic capabilities between exploitation and exploration (Benner and Tushman, 2003). From the above arguments, it can be hypothesised that TQM index and performance of R\&D are positively correlated.

H5 TQM index has a positive effect on performance of R\&D.

\subsubsection{Technical competency and $R \& D$ productivity}

It is essential that sound R\&D organisations having a better market share to stay competitive in the global market. A number of researchers have highlighted the importance of knowledge and scientific capabilities to competitive advantage (Deeds et al., 1997; Henderson and Cockburn, 1994; Hill and Deeds, 1996; Kogut and Zander, 1992; Petraff, 1993). It is particularly important for an organisation concerned about its future success to be preemptive in its development and alignment of competencies in order to lead the way into new products and services (Hamel and Prahalad, 1994). In many cases, research is more than just performance driving technologies for future products and these assertions lead to the following hypothesis:

H6 Technical competency has a positive effect on R\&D productivity.

\subsubsection{Performance of $R \& D$ and $R \& D$ effectiveness}

The $R \& D$ effectiveness index provides insights into the dynamics of the product development process and how it affects profitability. In fact, the R\&D effectiveness index itself is the result of key drivers of the product development process (McGrath and Romeri, 1994). The R\&D effectiveness index is an aggregate measure of the overall success of a company's R\&D performance efforts. It fills the void for an overall metric at a level above individual products and development projects, and provides management with a tool to measure the long-term effectiveness of its product strategy and product development process (Griffin and Page, 1993; Morbey, 1988; Wheelwright and Clark, 1992). These observations support making the following hypothesis:

H7 Performance of R\&D has a positive effect on R\&D effectiveness. 


\subsection{The SEM approach}

Structural equation models (SEMs) describe relationships between variables. They are similar to combining multiple regression and factor analysis. SEMs also offer some important, additional benefits over these techniques including an effective way to deal with multi-collinearity, and methods for taking into account the unreliability of survey response data.

Structural equation modelling (SEM) is recognised as a more comprehensive and flexible approach to research design and data analysis than any other single statistical model (Lattin et al., 2009). It takes a confirmatory approach that specifies inter-variable relations a priori, and estimate measurement errors explicitly (Maruyama, 1998). Therefore, the use of SEM in a confirmatory way is recommended especially if the purpose is to conform or reject the proposed hypotheses (Hafeez et al., 2006).

In comparison to other multivariate techniques, SEM applies only the variance/covariance or correlation matrix as its input data. Therefore, focus of SEM is not to be understood as individual observation, but as a pattern of relationships across the samples (Hair et al., 2005). In addition, SEM is a comprehensive statistical approach to test hypotheses about relations among constructs shown in Table 9. Every construct is linked to at least one variable that is measurable, thus making its measurement feasible (Bryrne, 1998).

Collecting the responses of questionnaire on a linguistic scale of strongly disagree to strongly agree, descriptive statistics were computed for responses to each statement in the questionnaire. The stem-and-leaf plots indicated that the data were normally distributed. The skewness of the distributions ranged from -1.09 to 0.46 , and the kurtosis ranged from -1.13 to 0.53 - insisting normality of the data and justifying the use of SEM on our data.

\section{Hypothesis testing}

The SEM approach was used to test the hypothesis. The SPSS AMOS 4.0 programme was used for the purpose (Figure 1). Figure 2 is a path diagram showing the hypothesised relationships among the constructs. The arrows indicate the direction of influence, and the numbers appearing on the arrows indicate the associated standardised regression weights obtained after using the AMOS 4.0 software package. The weights are significant with $p<.01$ each.

Table 10 gives the computed values of various indices. Columns 1, 2, and 3 give the chi-square $\left(\chi^{2}\right)$, degree of freedom (DF), and their ratio respectively. Column 4,5 , and 6 give the value of goodness of fit index (GFI), normalised fit index (NFI), and root mean square error approximation (RMSEA) of the model. The parameters indicate that the model is reliable (Arbuckle, 1997; Hafeez et al., 2006) and we can use this model to predict the relationships among the constructs. Column 4, 5, and 6 give the value of GFI, NFI, and RMSEA of the model. Here, GFI and NFI values are more than 0.9 and RMSEA value is less than 0.05 , which justify the fitness of the model. The parameters indicate that the model is reliable (Arbuckle, 1997; Hafeez et al., 2006) and we can use this model to predict the relationships among the constructs. 
Figure 1 SEM using AMOS-4.0

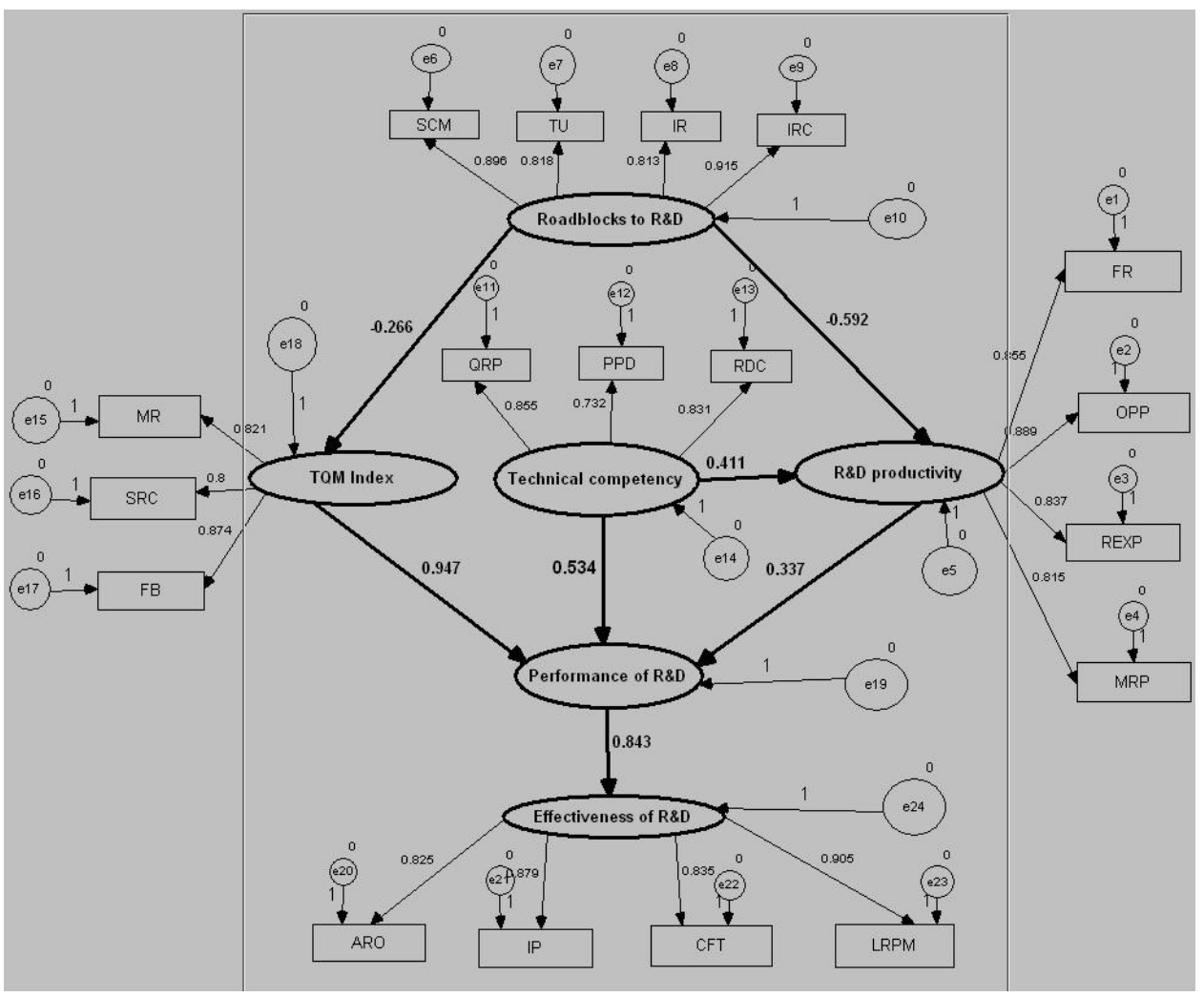

Figure 2 Results of the path model

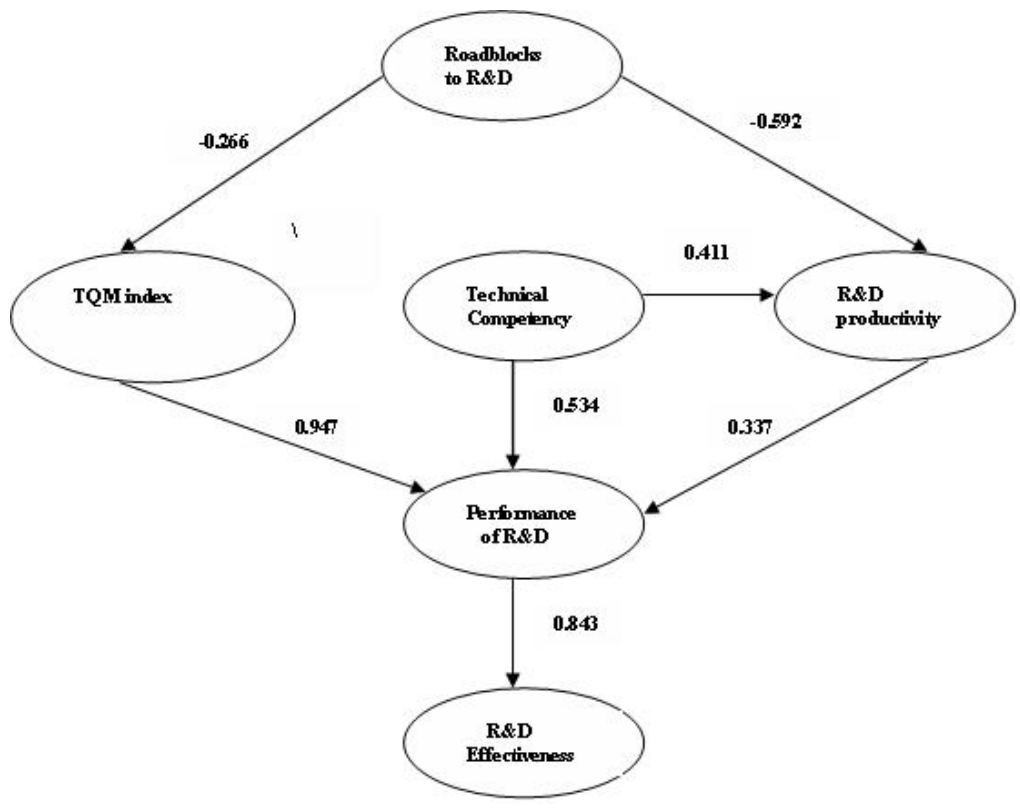


Table 10 Model fitting parameters

\begin{tabular}{llcccc}
\hline$\chi^{2}$ & $D F$ & $\chi^{2} / D F$ & $G F I$ & $N F I$ & $R M S E A$ \\
\hline 526.30 & 183 & 2.875 & 0.904 & 0.913 & 0.0443 \\
\hline
\end{tabular}

\section{Results and discussion}

The path analysis presented in Figure 2 is based on the empirical data collected from various manufacturing $\mathrm{R} \& \mathrm{D}$ organisations from India. The standardised regression weight indicated on the branches in the path diagram was used to accept or reject the hypothesis. Following Hair et al. (2005), Hung and Lu (2008), and Lattin et al. (2009), the hypotheses corresponding to standardised regression weight less than 0.1 were refuted. All the seven hypotheses were supported at $1 \%$ level of significance (Table 11).

Table 11 Results of the hypothesis

\begin{tabular}{clcc}
\hline Hypothesis & \multicolumn{1}{c}{ Description } & $\begin{array}{c}\text { Standardised } \\
\text { regression weight }\end{array}$ & Inference drawn \\
\hline H1 & $\begin{array}{l}\text { R\&D productivity has a positive } \\
\text { effect on performance of R\&D }\end{array}$ & 0.337 & Supported \\
H2 & $\begin{array}{l}\text { Roadblocks to R\&D has a negative } \\
\text { effect on R\&D productivity }\end{array}$ & -0.592 & Supported \\
H3 & $\begin{array}{l}\text { Technical competency has a positive } \\
\text { effect on performance of R\&D }\end{array}$ & 0.534 & Supported \\
H4 & $\begin{array}{l}\text { Roadblocks to R\&D has a negative } \\
\text { effect on TQM index }\end{array}$ & -0.266 & Supported \\
H5 & $\begin{array}{l}\text { TQM index has a positive effect on } \\
\text { performance of R\&D } \\
\text { Technical competency has a positive } \\
\text { effect on R \& D productivity }\end{array}$ & $\begin{array}{l}\text { Performance of R\&D has a positive } \\
\text { effect on R\&D effectiveness }\end{array}$ & 0.411 \\
H7 & & 0.843 & Supported \\
\hline
\end{tabular}

This study focuses significant perceptivities related to the importance of $R \& D$ performance measurement of Indian manufacturing organisations. The specific results of the survey and the interpretation of the results obtained in the context of objectives as set are summarised below.

- Table 11 shows that the standardised regression weight takes the highest value (0.947) for the positive effect of TQM index on performance of R\&D and encourages the R\&D effectiveness.

- Roadblocks to R\&D puts barrier to achieve TQM index and R\&D productivity, which affects the performance of R\&D severely.

- Technical competency is a key capability for R\&D productivity, which enhance the performance of R\&D productivity. Finally, better performance of R\&D accelerates the R\&D effectiveness. 


\section{Conclusions}

Performance measurement of R\&D activity is gaining increased importance because the effectiveness and efficiency of these activities not only determine a firm's competitive advantage, but its very survival. However, the complexity of measurement problems in $\mathrm{R} \& \mathrm{D}$ organisations has resulted in a situation where there is a scarcity of generally accepted techniques.

In this paper, an attempt has been made to study and identify the factors for success and barriers of performance measurement of R\&D of Indian manufacturing organisations. An analysis of the responses to the questionnaire, together with the use of factor analysis and PCA, helped in framing broad constructs of factors. Using these broad categories of factors, a number of hypotheses have been developed to find the causal relationships among them.

In this study, we analysed the structural relations among R\&D productivity, technical competency, TQM index, R\&D effectiveness, and roadblocks to R\&D. This empirical research outcomes based on the fitted SEM brings interesting results. The results indicate that TQM index and technical competency hold the key to achieve the R\&D effectiveness in Indian manufacturing organisations. Different components such as R\&D cycle time, quality and size of R\&D personnel, R\&D collaboration, and products and processes developed should be strengthen to create a support to technical competency and TQM index. TQM introduces new concepts to the process and presents a collaborative learning opportunity with opening the dialogue channels within and between the organisations. It is believed that the capability of technology by $R \& D$ firms plays a positive role in improving their performance and driving overall economic growth. Research and Development managers can utilise the feedback information found from SEM analysis for the enhancement of R\&D performance. The study presented here will help the research and development managers in identifying the areas in which they need to focus their attention in order to improve research and development performance.

\section{References}

Akcakaya, R. (2001) Procedure for the Assessment of R\&D Performance for a Manufacturing Company, Doctoral dissertation, Institute for Graduate Studies in Pure and Applied Sciences, Marmara University, Istanbul, Turkey.

Arbuckle, J. (1997) AMOS User's Guide Version 3.6, Smallwaters Corporation, USA.

Barney, J. (1991) 'Firm resources and sustained competitive advantage', Journal of Management, Vol. 17, No. 1, pp.99-120.

Benner, M.J. and Tushman, M.L. (2003) 'Exploitation, exploration, and process management: the productivity dillema revisited', Academy of Management Review, Vol. 28, No. 2, pp.238-256.

Bigliardi, B. and Dormio, A.I. (2010) 'A balanced scorecard approach for R\&D: evidence from a case study’, Facilities, Vol. 28, Nos. 5/6, pp.278-289.

Boutellier, R., Zedtwitz, M.V. and Gassmann, O. (2008) Managing Global Innovation: Uncovering the Secrets of Future Competitiveness, 3rd ed., Springer Publication, Berlin.

Brockhoff, K. (2003) 'Customers' perspectives of involvement in new product development', International Journal of Technology Management, Vol. 26, Nos. 5/6, pp.464-481.

Brown, W.B. and Gobeli, D. (1992) 'Observations on the measurement of R\&D productivity: a case study', IEEE Transactions on Engineering Management, Vol. 39, Nos. 4, pp.325-332. 
Bryrne, B.M. (1998) 'Basic concepts, applications, and programming', Structural Equation Modeling with AMOS, Lawrence Erlbaum, Mahwah, NJ.

Chandra, P. (2009) 'Competitiveness of Indian manufacturing', Findings of the Third National Manufacturing Survey, Report submitted to the National Manufacturing Competitiveness Council, India.

Chiesa, V. and Masella, C. (1996) 'Searching for an effective measure of R\&D performance', Management Decision, Vol. 34, No. 7, pp.49-57.

CMIE (2009) Prowess: Firm Level Data Services, Centre for Monitoring Indian Economy PrivateLimited, Mumbai, India, available at http://www.cmie.com.

Coccia, M. (2003) 'New models for measuring the R\&D performance and identifying the productivity of public research institutes', $R \& D$ Management, Vol. 34, No. 3, pp.267-280.

Cooper, R.G. and Kleinschmidt, E. (1996) 'Winning businesses in product development: the critical success factors', Research Technology Management, Vol. 39, No. 4, pp.18-29.

Curtis, C.C. and Ellis, L.W. (1997) 'Balanced scorecards for new product development', Journal of Cost Management, May-June, pp.12-18.

Deeds, D., DeCarolis, D. and Coombs, J. (1997) 'The impact of firm specific capabilities on the amount of capital raised in an initial public offering: evidence from the biotechnology industry', Journal of Business Venturing, Vol. 12, No. 1, pp.31-46

Ding, Y. (2007) 'R\&D productivity: an exploratory international study', Review of Accounting and Finance, Vol. 6, No. 1, pp.86-101.

Driva, H., Pawar, K.S. and Menon, U. (2000) 'Measuring product development performance in manufacturing organisations', International Journal of Production Economics, Vol. 63, No. 2, pp.147-159.

Frattini, F., Lazzarotti, V. and Manzini, R. (2006) 'Towards a system of performance measures for research activities: NiKem research case study', International Journal of Innovation Management, Vol. 10, No. 4, pp.425-454.

Freeman, C. and Soete, L. (2009) 'Developing science, technology and innovation indicators: what we can learn from the past', Research Policy, Vol. 38, No. 4, pp.583-589.

Fritsch, M. and Lukas, R. (2001) 'Who cooperates on R\&D?', Research Policy, Vol. 30, No. 2, pp.297-312.

García-Valderrama, T., Mulero-Mendigorri, E. and Revuelta-Bordoy, D. (2008) 'A balanced scorecard framework for R\&D’, European Journal of Innovation Management, Vol. 11, No. 2, pp.241-281.

Germerrad, P. (2003) 'Measuring R\&D in 2003', Research Technology Management, November/December, Vol. 46, No. 6, pp.47-56.

Griffin, A. and Page, A.L. (1993) 'An interim report on measuring product development successes and failure', Journal of Product Innovation Management, Vol. 10, No. 4, pp.291-308.

Griffiths, W. and Webster, E. (2010) 'A balanced scorecard approach for R\&D: evidence from a case study', Facilities, Vol. 28, Nos. 5/6, pp.278-289.

Guan, J. and Ma, N. (2003) 'Innovative capability and export performance of Chinese firms', Technovation, Vol. 23, No. 9, pp.737-747.

Guellecb, D. and Van Pottelsberghe, B. (2003) From R\&D to Productivity Growth: Do the Institutional Settings and the Source of Funds of R\&D Matter?, Working papers, Université Libre de Bruxelles, Solvay Business School, Centre Emile Bernheim (CEB).

Gupta, A.K., Wilemon, D. and Atuahene-Gima, K. (2000) 'Excelling in R\&D', Research Technology Management, Vol. 43, No. 3, pp.52-59.

Hafeez, K., Keoy, K.H. and Hanneman, R. (2006) 'E-business capabilities model validation and comparison between adopter and non-adopter of e-business companies in UK', Journal of Manufacturing Technology Management, Vol. 17, No. 6, pp.806-828.

Hair, J.F., Jr., Anderson, R.E., Tatham, R.L. and Black, W.C. (2005) Multivariate Data Analysis, 5th ed., 2nd Indian reprint, Pearson Education, Inc., New Delhi, India. 
Hamel, G. and Prahalad, C.K. (1994) Competing for the Future, Harvard Business School Press, Boston, Mass.

Harrington, H.J. (1994) Total Improvement Management: The Next Generation in Performance Improvement, Tata McGraw-Hill edition, London.

Henderson, R. and Cockburn, I. (1994) 'Measuring competence? Exploring firm effects in pharmaceutical research (special issue)', Strategic Management Journal, Vol. 15, No. 15, pp.63-84.

Heshmati, A. and Loof, H. (2005) Sources of Finance, R\&D Investment and Productivity: Correlation or Causality?, Working paper series in Economics and Institutions of Innovation, CESIS.

Hill, C.W.L. and Deeds, D.L. (1996) 'The importance of industry structure for the determination of firm profitability', Journal of Management Studies, Vol. 33, No. 4, pp.429-451.

Hitt, M.A., Hoskisson, R.E. and Ireland, R.D. (1994) 'A mid-range theory of the interactive effects of international and product diversification on innovation and performance', Journal of Management, Vol. 20, No. 2, pp.297-326.

Howells, J. (2008) 'New directions in R\&D: current and perspectives challenges', $R \& D$ Management, Vol. 38, No. 3, pp.241-252.

Hung, Y-C. and Lu, Y-H. (2008) 'The inhibitory factors of implementing internet banks', International Journal of Electronic Finance, Vol. 2, No. 4, pp.419-432.

Jayawarna, D. and Holt, R. (2009) 'Knowledge and quality management: an R\&D perspective', Technovation, in press, corrected proof.

Kerssen-van Drongelen, I.C. and Cook, A. (1997) 'Design principles for the development of measurement systems for research and development processes', R\&D Management, Vol. 27, No. 4, pp.345-357.

Kim, B. and Oh, H. (2002) 'An effective R\&D performance measurement system: survey of Korean R\&D researchers', Omega, Vol. 30, No. 1, pp.19-31.

Kogut, B. and Zander, U. (1992) 'Knowledge of the firm, combinative capabilities and the replication of technology', Organization Science, Vol. 3, No. 3, pp.383-396.

Kuittinen, H. (2007) 'Sectoral and firm-level differences in innovation performance: evidence from Finnish manufacturing firms', Contributed paper for the 2007 Conference on Corporate $R \& D$.

Lattin, J., Carroll, J.D. and Green, P.E. (2009) Analyzing Multivariate Data, 2nd Indian reprint, Brooks/Cole Cengage Learning, India.

Lee, C-Y. (2009) 'Competition favors the prepared firm: firms' R\&D responses to competitive market pressure', Research Policy, Vol. 38, No. 5, pp.861-870.

Lee, X., Xie, N. and Pang, L. (2008) 'Empirical analysis of R\&D capability in China's automotive firms', IEEE Xplore, 10.1109/PICMET.2008.4599635, pp.294-303.

Loch, C.H. and Tapper, U.A.S. (2002) 'Implementing a strategy-driven performance measurement system for an applied research group', The Journal of Product Innovation Management, Vol. 19, No. 3, pp.185-198.

Maruyama, G.M. (1998) Basic of Structural Equation Modeling, Sage Publication, London, UK.

McGrath, M.E. and Romeri, M.N. (1994) 'The R\&D effectiveness index: a metric for product development performance', World Class Design to Manufacture, Vol. 1, No. 4, pp.24-31.

Mitra, R.M. (2007) India's Emergence as a Global R\&D Center, Working Paper R2007:012, ITPS, Swedish Institute for Growth Policy Studies, Sweden.

Morbey, G.K. (1988) 'R\&D: its relationship to company performance', Journal of Innovation Management, Vol. 5, No. 3, pp.191-200.

Narayanan, K. and Bhat, S. (2009) 'Technology sourcing and its determinants: a study of basic chemical industry in India', Technovation, Vol. 29, No. 8, pp.562-573.

National S\&T Survey (2005) Department of Science and Technology, New Delhi. 
Nemet, G.F. (2009) 'Demand-pull, technology-push, and government-led incentives for nonincremental technical change', Research Policy, Vol. 38, No. 5, pp.700-709.

O'Mahony, M. and Vecchi, M. (2009) 'R\&D, knowledge spillovers and company productivity performance', Research Policy, Vol. 38, No. 1, pp.35-44.

Pereda, J., Hincapie, M. and Molina, A. (2008) 'Product, process and manufacturing system lifecycles analysis for a concurrent development', International Conference on Product Lifecycle Management (PLM08), Vol. 2, No. 1, pp.79-89.

Petraff, M. (1993) 'The cornerstone of competitive advantage: a resource-based view', Strategic Management Journal, Vol. 14, No. 3, pp.179-191.

Prajogo, D.I. and Sohal, A.S. (2006) 'The integration of TQM and technology/R\&D management in determining quality and innovation performance', Omega, Vol. 34, pp.296-312.

Pulkkinen, A. and Riitahuhta, A. (2009) 'On the relation of business processes and engineering change management', International Conference on Product Lifecycle Management (PLM09), Vol. 1, No. 1, pp.36-45.

Roy, S., Nagpaul, P.S. and Mohapatra, P.K.J. (2003) 'Developing a model to measure the effectiveness of research units', International Journal of Operations \& Production Management, Vol. 23, No. 12, pp.1514-1529.

Sen, F. and Rubenstein, A.H. (1989) 'External technology and in-house R\&D's facilitative role', Journal of Product Innovation Management, Vol. 6, No. 2, pp.123-138.

Sink, D.S. (1985) Productivity Management: Planning, Measurement and Evaluation, Control and Improvement, John Wiley \& Sons Inc., USA.

Smith, M.K. and Ball, P.D. (2007) 'Linking organizational innovation and product lifecycle management', International Conference on Product Lifecycle Management (PLM07), Vol. 1, No. 1, pp.43-52.

Sunil, M. (2001) Role of Government in Promoting Innovation in the Enterprise Sector an Analysis of the Indian Experience, Discussion papers from United Nations University, Institute for New Technologies.

Swain, A.K., Sen, D. and Gurumoorthy, B. (2009) 'Associativity between product model and process model', International Conference on Product Lifecycle Management (PLM09), Vol. 1, No. 1, pp.3-14.

Tsai, K-H. (2009) 'Collaborative networks and product innovation performance: toward a contingency perspective', Research Policy, Vol. 38, No. 5, pp.765-778.

Werner, B.M. and Souder, W.E. (1997) 'Measuring R\&D performance - US and German practices', Research Technology Management, Vol. 40, No. 3, pp.28-32.

Wharton Knowledge (2005) How R\&D Is Changing Indian Pharma and Auto Companies, available at http://knowledge. wharton.upenn.edu/india/article.cfm?articleid=4048,1-5.

Wheelwright, S.C. and Clark, K.B. (1992) Revolutionizing Product Development, The Free Press, New York.

Zahra, S.A., Ireland, R.D. and Hitt, M.A. (2000) 'International expansion by new venture firms: international diversity, mode of market entry, technology learning, and performance', Academy of Management Journal, Vol. 43, No. 5, pp.925-950.

Zhang, W., Zhang, Z. and Han, G. (2010) 'How does the US credit crisis affect Asia-Pacific economies? Analysis based on a general equilibrium model', Journal of Asian Economics, Vol. 21, No. 4, pp.280-292. 